Technological University Dublin

ARROW@TU Dublin

\title{
Fifty Years of the Strategic Trade-Offs Model: In Memory and Honor of Wickham Skinner
}

\author{
Roberto Sarmiento \\ UASLP, San Luis Potosi \\ Garvan Whelan \\ Technological University Dublin, garvan.whelan@tudublin.ie \\ Matthias Thürer \\ Jinan University - China
}

See next page for additional authors

Follow this and additional works at: https://arrow.tudublin.ie/buschmanart

Part of the Business Administration, Management, and Operations Commons, and the Strategic Management Policy Commons

\section{Recommended Citation}

R. Sarmiento, G. Whelan, M. Thürer and F. A. Bribiescas-Silva, "Fifty Years of the Strategic Trade-Offs Model: In Memory and Honor of Wickham Skinner," in IEEE Engineering Management Review, vol. 47, no. 2, pp. 92-96, 1 Secondquarter,june 2019, doi: 10.1109/EMR.2019.2915978.

This Article is brought to you for free and open access by the School of Management at ARROW@TU Dublin. It has been accepted for inclusion in Articles by an authorized administrator of ARROW@TU Dublin. For more information, please contact arrow.admin@tudublin.ie, aisling.coyne@tudublin.ie,gerard.connolly@tudublin.ie.

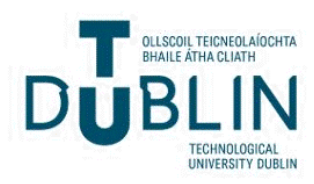




\section{Authors}

Roberto Sarmiento, Garvan Whelan, Matthias Thürer, and Francisco Arturo Bribiescas-Silva 


\title{
Fifty Years of the Strategic Trade-Offs Model: In Memory and Honor of Wickham Skinner
}

\section{-ROBERTO SARMIENTO \\ UASLP, San Luis Potosi 78290, Mexico}

-GARVAN WHELAN

ITT Dublin, Dublin D24 FKT9, Ireland

- MATTHIAS THÜRER

Jinan University, Guangzhou 510290, China

-FRANCISCO ARTURO

BRIBIESCAS-SILVA

UACJ, Juarez 32310, Mexico

(Corresponding author: Roberto Sarmiento.)

IEEE DOI 10.1109/EMR.2019.2915978

\begin{abstract}
In 1969, Professor Wickham Skinner, whom many consider as "the father of manufacturing strategy," published a seminal paper entitled "Manufacturing-Missing Link in Corporate Strategy." Among the many interesting insights outlined in that article, Skinner is particularly careful to explain the importance of acknowledging the existence of specific trade-offs in the design of production systems. For example, he warns that a failure on the part of executives to recognize the limitations and compromises that are inherent to all technology and human based systems will inevitably result in a diminished ability of firms to compete successfully in the marketplace. Fifty years after the publication of that influential paper, we reassess some of Professor Skinner's contributions to the theory and practice of strategic operations management. In particular, we put forth the argument that strategic trade-offs in the operations of firms is a concept that is still-and will continue to be-important and relevant to practitioners worldwide.
\end{abstract}

Key words: Wickham Skinner, strategic trade-offs, manufacturing strategy, business strategy, corporate strategy, competitive capabilities

\section{INTRODUCTION}

W HILE working on previous drafts of this article, we, as members of the operations management (OM) community, received the sad news that Professor Wickham Skinner had passed away on January of this year. Having completed research based on some of his ideas, we are especially appreciative of his invaluable insights and contributions to the theory and practice of operations management. Therefore, this article will serve both as a small and humble celebration of his life and legacy, and, also as a repositioning of his "strategic tradeoffs" model. Our previous investigations on this particular topic allow us to articulate the argument that when viewed in its proper context, strategic trade-offs is a concept that -contrary to what has been argued by some researchershas key implications vis-à-vis the adequate design and management of manufacturing and service firms.
The rest of the paper follows this structure. Section 2 offers a brief biographical note on Professor Wickham Skinner. Section 3 presents some clarifications of the "strategic trade-offs" concept. Major implications for practitioners are then outlined in Section 4, before Section 5 discusses future research opportunities. Finally, conclusions are summarized in Section 6.

\section{Professor WickHAM SKINNER: A BIOGRAPHICAL NOTE}

Upon graduating from Yale University with a degree in Chemical Engineering, Professor Skinner was "immediately inducted into the Army", and afterwards, he was assigned to work on the Manhattan Project at Los Alamos, getting involved in the manufacturing and engineering tasks necessary to build the first bombs [Hayes, 2002]. After earning an MBA from Harvard Business School and 
working for several years in the private sector, Professor Skinner decided to return to Harvard to pursue doctoral studies, receiving his PhD in $1961 .{ }^{1}$

At Harvard, Professor Skinner went on to have a distinguished career as a teacher, researcher, mentor and administrator. Among his various distinctions and honors, he was elected a Fellow of the Academy of Management in 1976. He received the same honor from the Production and Operations Management Society (POMS), when he was elected a Fellow in 2004. Furthermore, this same society named an award after him in order to "encourage POM scholarship and publication, to promote significant research in the field, to reward academics who have achieved unusually high accomplishment early in their careers, and to facilitate the sharing of innovative new ideas about teaching POM". Additionally, he received an honorary doctorate from the University of Ghent in 2002.

Commenting on the extent to which Professor Skinner has influenced the teaching, theory and practice of strategic operations management, Hayes (2002) notes that at Harvard, Professor Skinner successfully taught several courses, and one in particular ("Advanced Production Problems") became "extraordinarily popular", always receiving high ratings from students when led by him. The relevance and importance of his research, including the "Missing Link"2 article [Skinner, 1969] were quickly acknowledged in industry, which made Professor Skinner a sought after consultant and speaker.

\footnotetext{
${ }^{1}$ The sources of the biographical material used in this section were: (both links accessed on 13 March 2019): https://www.hbs.edu/news/ releases/Pages/c-wickham-skinner-obituary. aspx http://poms.org/skinnerawardsintroduction.pdf Hayes (2002), see references section. Sprague (2007) see references section.

${ }^{2}$ As of 14 March 2019, this paper has 3015 citations in Google Scholar.
}

He was the author or co-author of over 75 articles and book chapters, published 10 books, and his Harvard Business Review articles have sold more than half a million reprints.

Professor Wickham Skinner's teachings, research and insights will continue to influence and inspire future generations of OM students, scholars and practitioners.

He will be greatly missed.

\section{Strategic Trade-Offs in THE OPERATIONS OF FIRMS: SOME CLARIFICATIONS}

It is our position that Professor Skinner's strategic trade-offs model has been a much-misunderstood concept. ${ }^{3}$ With this in mind, this section briefly explains the nature and consequences of this theory.

In his 1969 paper, Skinner puts forth the argument that "a production system inevitably involves trade-offs and compromises and so must be designed to perform a limited task well, with that task defined by corporate strategic objectives"

(p. 138). To understand the full implications of Skinner's model, it is essential to note that in that seminal article, he clearly makes the argument that the existence of trade-offs in the design of products or services necessarily imply the existence of trade-offs in the design and operations of manufacturing or service firms (p. 140):

Yet most managers will readily admit that there are compromises or trade-offs to be made in designing an airplane or a truck. In the case of an airplane, trade-offs would involve such matters as cruising speed, takeoff and

\footnotetext{
${ }^{3}$ This view has been developed over a series of papers. To achieve brevity, we refer the reader to Sarmiento, Whelan, and Thurer (2018) and Sarmiento, Thurer, and Whelan (2016) for recent analyses of the literature on strategic trade-offs and related topics.
}

landing distances, initial cost, maintenance, fuel consumption, passenger comfort, and cargo or passenger capacity.

Much the same thing is true of manufacturing. The variables of cost, time, quality, technological constraints, and customer satisfaction place limits on what management can do, force compromises, and demand an explicit recognition of a multitude of trade-offs and choices.

In his studies, Skinner found that a lack of acknowledgement of these trade-off relationships would result in inefficiencies that could hamper the ability of firms to compete in the marketplace (p. 140):

Yet everywhere I find plants which have inadvertently emphasized one yardstick at the expense of another, more important one.

....[consequently] customers were more dissatisfied than ever. Product managers hotly complained that delivery promises were regularly missed-and in almost every case they first heard about failures from their customers.

It appears as if Skinner's ideas regarding the existence of strategic trade-offs went unchallenged for a number of years. However, this started to change in the 1980s and 1990s, when researchers began to question the validity of the trade-offs model, ${ }^{4}$ arguing for example that there are synergy effects that allow firms to obtain an advantage across a number of competitive capabilities. In response to those arguments,

\footnotetext{
${ }^{4}$ This questioning has continued to more recent times, when some researchers have even argued that "in practice, the trade-offs model is not used" [Singh et al., 2015, p. 4001]. See Sarmiento, Whelan, and Thurer (2018) for a detailed analysis of this particular claim against Skinner's proposal of strategic trade-offs.
} 
Skinner $(1992,1996)$ offered a more detailed explanation of his theory. In particular, he advanced the following proposition (1996, p. 6):

Choices must be made; tradeoffs are inevitable; one system cannot be outstanding enough at meeting all criteria to create competitive advantage.

We refer the reader to Sarmiento, Thurer, and Whelan (2016) for a technical analysis of Skinner's proposition. Here we only discuss a few important consequences of his statement. The nature of Skinner's hypothesis is universal in its scope. This means that, according to him, it is impossible for a technology and human based system to operate without trade-offs. Put differently, Skinner affirms that there is no manufacturing or service system in which some form of trade-off between at least one pair of competitive capabilities (e.g., quality, cost) does not exist. Also, we posit that the expression "one system cannot be outstanding enough at meeting all criteria to create competitive advantage" can be fairly characterized as: "No manufacturing or service firm can be the best at everything (e.g., delivery, cost, quality, environmental competitiveness)".

The assertion that no manufacturing or service firm can be the best at everything has important implications for research (and practice). In our investigations on this topic, we have observed that, almost without exception, all previous studies have collected information from manufacturing or service firms in order to investigate whether trade-offs exist.
This information is often provided by executives, who are asked, for example, to make assessments of their firms' performance across various competitive capabilities. While this way of doing research on strategic tradeoffs has its advantages, we think that there is another, more adequate form in which this topic can be investigated.

Referring back to Skinner's [1969] explanation about the existence of trade-offs, it is important to underline that he interlinks the existence of compromises in the design and performance of products with trade-offs in the design and operations of systems (140):

\section{.... there are compromises or}

trade-offs to be made in

designing an airplane or a truck.

Much the same thing is true of manufacturing.

In our view, it is clear that Skinner emphasizes the idea that just as there are trade-offs in the design and performance of individual products or services, there also must be, necessarily, compromises in the design and operations of the (manufacturing or service) systems that produce them. Once this interrelationship has been established, one of its logical consequences can also be clarified. We argue that a statement such as "no manufacturing or service firm can be the best at everything", by necessity, entails a similar universal proposition along the lines of "no product or service can be the best at everything".

Viewed in this way, it becomes less difficult to understand and corroborate

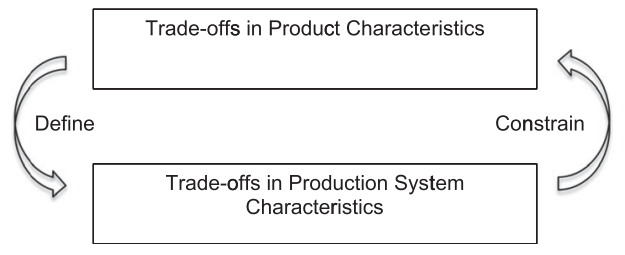

Figure 1. Interlinked relationship between an output and its respective production system.

if Skinner's proposal of strategic tradeoffs in the design and operations of firms is consistent with everyday evidence. We suggest that researchers interested in this topic can analyze, for example, pairs of competing products or services in order to determine whether it is possible for individual goods to be the best at everything (e.g., price, availability of products/services, quality features, environmental performance, etc.). We further discuss these ideas in the next sections.

\section{Discussion of Practical IMPLICATIONS}

In the previous sections, we clarified the underlying concept behind Skinner's proposal for the existence of strategic trade-offs in the operations of firms. We suggested that, to understand Skinner's model more comprehensively, it is recommended to analyze carefully the characteristics of individual goods and/or services, and the potential consequences on the overall policies that govern the design and operations of manufacturing and/ or service systems. Skinner basically argues that just as there are compromises in the design and performance of individual products or services, there also must be, necessarily, trade-offs in the design and operation of the entire systems that produce them. This allows us to suggest that while the product characteristics define the required production system characteristics, the production system characteristics constrain the product characteristics (see Figure 1). In other words, the actual trade-off occurs at the production system level while it is more visible at the product level.

The implications of this core premise, we opine, should be of guidance to practitioners and researchers worldwide. Would it be realistic to run a business with a strategy that aims at designing and offering to customers products and/or services that can be 
"the best at everything"? To crystalize this question further, we invite the reader to think of the potential answers to the following two questions:

1. Will it ever be possible to build a BMW using the same entire supply chain system that produces a Skoda at the same (low) production cost?

2. Will it ever be possible to build a (high quality) Macbook laptop using the same entire supply chain system that produces a Dell laptop at the same (low) production cost?

Similar questions can be asked visà-vis pairs of competing products or services across all economic sectors and activities. It should be clarified that we are not closed to the idea of new technological breakthroughs that would make it possible to build products or services that could be the "best at everything". But even if this could be accomplished, ${ }^{5}$ we also think that Professor Skinner's proposal of strategic trade-offs is consistent with evidence that consumers of everyday goods and services can corroborate. We opine that insomuch as the production of goods and services that we all consume remains dependent on systems that are technology and human based, there will always be some form of trade-off that will need to be accounted for.

One of the most important and practical implications of Professor Skinner's works is the idea that factories adopting a "focused"6 approach would become more

\footnotetext{
${ }^{5}$ In a personal communication with the first author of this article, Professor Roger Schmenner affirmed that a product outperforming its competitors across all measures of performance was already built: the transistor radio. The implication of this is that, at least in some contexts, it is possible to build products or services that could be the best at everything.

${ }^{6}$ A "focused factory" (as in Skinner, 1974) is one whose "'entire apparatus is focused to accomplish the particular manufacturing task demanded by [its specific] strategy ...."' [Hayes, 2002, p. 5].
}

competitive. Is there empirical evidence that corroborates this assertion? Hayes (2002) writes about the case of the Copeland

Corporation, whose CEO "decided to "bet the company" by investing all its available capital into building a new, focused factory for the company's major product line" (p. 5). The results of this decision, according to Hayes (2002, p. 5), were remarkable: "Within 5 years the competitive advantages provided by this set of focused factories had forced two big competitors to drop out of the business, and Copeland's worldwide market share rose from 15\% to 60\%".

Critics could reasonably say that the above is just an anecdotal example. While this may be a valid point, it can also be said that, once specific tradeoffs in the design of goods and/or services have been identified, executives and managers would do well to design and operate entire supply chains taking into consideration those compromises. In other words, we think that it would be unwise on the part of, for example, Apple executives, to attempt to produce Macbook Pro laptops with the same supply chain system that builds Dell laptops. Doing so, we think, would result in inefficiencies that would hinder Apple's ability to compete successfully in the marketplace.

It is important to note that in Skinner's view, the term "focused factory" does not mean that a manufacturing operation should focus on one specific product. Rather it means focused on core capabilities. For example, Henry Ford focused on its Model T which resulted in efficiencies including high production volumes at a low cost per unit. Subsequently, however, it took him several months to introduce a new model (during these months nothing was produced since the whole production system had to be set up anew). This meant that the focus on a specific product led to production shortfalls which allowed a competitive advantage to rivals such as GM. In this context, the focus should have been on the capability to produce large volumes (and thus low unit cost) independent of the product manufactured.

Summarizing the main implications of Professor Skinner's works for practitioners, we can say that the available evidence tells us that there are trade-offs in the design of individual products and/or services. According to this theory, these compromises are due to the limitations that are inherent to all technology and human based systems. Consequently, executives and managers should design and operate entire supply chains taking into consideration these trade-offs. A failure to do so, Professor Skinner warns, would limit a firm's ability to compete.

\section{Future Research}

In terms of scientific research, there are a few areas that need further investigation. For example, Professor Schmenner's idea (see footnote 5) that it is possible to build products and/or services that could be the best at everything needs to be explored in more detail. Let us concede for a moment that technological breakthroughs could make it possible to build goods and services that would outperform all established competitors across all measures of performance. This scenario notwithstanding, it also appears as if there is a point in the development/maturing of technologies and/or market conditions where firms have to make decisions vis-à-vis the design and operations of systems that are consistent with the dictates of Professor Skinner's trade-offs model. What we are saying here is that even if Schmmener were correct in his comments, this situation would not refute at all the practical implications and empirical "validity" of Professor Skinner's model. ${ }^{7}$ Perhaps there is a

\footnotetext{
${ }^{7}$ This would be akin to the empirical "validity" of Newton's laws. Although Newtonian physics are generally considered to be false [Dienes, 2008], there is no denying their practical applications and utility.
} 
scientific theory waiting to be advanced (and tested) that would encompass both Schmenner's proposal and Professor Skinner's ideas.

There are also opportunities to explore the potential trade-offs involved in the implementation of green initiatives. Sarmiento and Vargas-Berrones (2018) and Bai and Sarkis (2018) have already proposed frameworks and methodologies that are useful to understand the conflicts that may exist among different environmental, societal and business targets. While their works are a welcome start, more investigations addressing the different compromises that firms might face when implementing environmentally friendly programs are needed.

\section{Conclusions}

This paper sought to clarify the trade-offs law and reemphasizes its importance in management practice. Taking a look back at the last 50 years, we can see that there have been fundamental and massive changes in the technologies that enable the manufacture and delivery of products and services.

Notwithstanding these technological developments, the trade-offs model continues to be of relevance for both practitioners and researchers involved in operations management. We hope that the ideas outlined in this paper will help to further unravel the important implications contained in the writings of Professor Wickham Skinner.

\section{REFERENCES}

Bai, C. and Sarkis, J. (2018). Honoring complexity in sustainable supply chain research: A rough set theoretic approach (SI: ResMeth). Production Planning \& Control, 29(16), 1367-1384.

Dienes, Z. (2008). Understanding psychology as a science. An Introduction to Scientific and Statistical Inference. Basingstoke, U.K.: Palgrave-Macmillan.

Hayes, R. H. (2002). Wick Skinner: A life sailing against the wind. Production and Operations Management, 11(1), 1-8.

Sarmiento, R., Thurer, M., and Whelan, G. (2016). Rethinking Skinner's model: Strategic trade-offs in products and services. Management Research Review, 39 (10), 1199-1213.

Sarmiento, R., Whelan, G., and Thürer, M. (2018). A note on "beyond the trade-off and cumulative capabilities models: Alternative models of operations strategy." International Journal of Production Research, 56(12), 4368-4375.

Sarmiento, R. and Vargas-Berrones, K. X. (2018). Modeling the implementation of green initiatives: An AHP-BOCR approach. Cogent Engineering, 5(1), 1432120.

Singh, P. J., Wiengarten, F., Nand, A. A., and Betts, T. (2015). Beyond the trade-off and cumulative capabilities models: Alternative models of operations strategy. International Journal of Production Research, 53(13), 4001-4020.

Skinner, W. (1969). Manufacturing-missing link in corporate strategy. Harvard Business Review, 47(3), 136-145.

Skinner, W. (1974). The focused factory. Harvard Business Review, 52(3), 113-121.

Skinner, W. (1992). Missing the links in manufacturing strategy. in Manufacturing Strategy: Process and Content, C. A. Voss, Eds. London, U.K.: Chapman and Hall, 13-25.

Skinner, W. (1996). Manufacturing strategy on the "S" curve. Production and Operations Management, 5(1), 3-14.

Sprague, L. G. (2007). Evolution of the field of operations management. Journal of Operations Management, 25(2), 219-238. 